\title{
Pomphorhynchus omarsegundoi sp. n. (Acanthocephala: Pomphorhynchidae), parasite of the banded knifefish Gymnotus carapo (Gymnotiformes: Gymnotidae) from the Paraná River basin, Argentina
}

\author{
Nathalia J. Arredondo and Alicia A. Gil de Pertierra
}

Laboratorio de Helmintología, Facultad de Ciencias Exactas y Naturales, Universidad de Buenos Aires, Buenos Aires, Argentina

\begin{abstract}
Pomphorhynchus omarsegundoi sp. n. from Gymnotus carapo Linnaeus from the Paraná River basin in Argentina is described in this paper. The new species is characterised by having a small body; a non-spirally twisted long neck forming an inconspicuous asymmetrical bulb more developed dorsally than ventrally; a proboscis almost cylindrical, with 11 to 12 longitudinal rows of 5 to 7 (usually 6) hooks each; presence of an apical organ; a mean neck/body ratio of about 1/8; and a post-equatorial male reproductive system, occupying $35-42 \%$ of total length. The new species can be easily distinguished from the other four South American pomphorhynchid species by the inconspicuous asymmetrical bulb and the lower number of hooks per row. Pomphorhynchus omarsegundoi is the second acanthocephalan recorded from G. carapo in the Paraná River basin.
\end{abstract}

Keywords: Acanthocephala, Pomphorhynchidae, Pomphorhynchus omarsegundoi, Gymnotus carapo, Argentina

Little information is currently available on the acanthocephalans from freshwater fishes from Argentina (Hamann 1982a-c, Vizcaíno and Lunaschi 1987, Ortubay et al. 1991, 1994, Vizcaíno 1992, Gil de Pertierra et al. 1996, Semenas and Trejo 1997), specially compared with other countries in South America (e.g., Schmidt and Hugghins 1973a, b, Thatcher 2006, Portes Santos et al. 2008).

During a survey of the parasite fauna of fishes of the Paraná River and Colastiné River (tributary of the Paraná River) in Argentina, specimens of an unknown acanthocephalan were found penetrating the intestinal wall of the banded knifefish Gymnotus carapo Linnaeus. In the present study the parasite is described as a new species.

\section{MATERIALS AND METHODS}

Fifty-eight specimens of Gymnotus carapo (Gymnotiformes: Gymnotidae) were examined for acanthocephalans. Fish were caught from the Colastiné River (tributary of the Paraná River) $\left(31^{\circ} 40^{\prime} \mathrm{S}, 60^{\circ} 46^{\prime} \mathrm{W}\right)$, Santa Fe Province, Argentina, in July 2001, December 2001-2004, February 2002, September 2002 and October 2007-2008; and from the Paraná-Guazú River (3354'S, $\left.58^{\circ} 52^{\prime} \mathrm{W}\right)$, Entre Ríos Province, Argentina, in November 2008, April 2009 and October 2009.

Acanthocephalans found in the intestine were washed in saline solution, placed in cold water for $12 \mathrm{~h}$, fixed in $4 \%$ formaldehyde solution and stored in $70 \%$ ethanol. Then, they were dehydrated through a gradual ethanol series and cleared in beechwood creosote, which allows the rotation of the specimen examined. Additionally, this material was compared with type material of Pomphorhynchus patagonicus Ortubay, Ubeda, Semenas et Kennedy, 1991 (MACN-Pa No. 358/1-8) and P. sphaericus Gil de Pertierra, Spatz et Doma, 1996 (MACN-Pa No. 377/1-6) both from Argentina, deposited in the Parasitological Collection of the Museo Argentino de Ciencias Naturales "Bernardino Rivadavia", Buenos Aires, Argentina.

The holotype, allotype and paratype specimens were deposited in the Parasitological Collection of the Museo Argentino de Ciencias Naturales "Bernardino Rivadavia", Buenos Aires, Argentina (MACN-Pa, see below) and in the Institute of Parasitology, České Budějovice (IPCAS, see below).

Measurements include the range followed by the mean in parentheses, and number of measurements (n). All measurements are in micrometres unless otherwise stated. Illustrations were made with the aid of a camera lucida attached to a Zeiss Axioscope microscope equipped with differential interference contrast optics.

\section{RESULTS}

Pomphorhynchus omarsegundoi sp. $\mathrm{n}$.

Fig. 1

Description (based on 8 specimens: 5 males, 2 females with well-developed ovarian balls and 1 immature without sexual differentiation): Palaeacanthocephala, Pomphorhynchidae, with the characters of the genus. Fresh individuals white. Worms small. Trunk cylindrical, slightly swollen at the anterior region. Neck long, not spi-

Address for correspondence: N.J. Arredondo, Laboratorio de Helmintología, Departamento de Biodiversidad y Biología Experimental, Facultad de Ciencias Exactas y Naturales, Pabellón II, $4^{\circ}$ Piso, Ciudad Universitaria, Int. Güiraldes 2160, Universidad de Buenos Aires, C1428EGA - Buenos Aires, Argentina. Phone: ++54 11 4576-3349; Fax: ++54 11 4576-3384; E-mail: arredondonj@bg.fcen.uba.ar 
rally twisted, broader at base, forming an inconspicuous asymmetrical bulb more developed dorsally than ventrally. Proboscis almost cylindrical, enlarged in the middle, possessing 11 to 12 longitudinal rows of 5 to 7 (usually 6) hooks each. Proboscis armature nearly equal in both sexes; usually, first, sixth and seventh hooks smaller and second to fifth longer, roots manubrium-shaped with anterior sheet smaller than posterior. Apical organ present. Proboscis receptacle long, double-walled, not complete posteriorly, extends for a short distance into body cavity; cerebral ganglion near posterior end. Lemnisci sub-equal, digitiform, longer than proboscis receptacle. Genital pore terminal in both sexes.

Male (based on 5 specimens): Trunk 6-12 $\mathrm{mm}$ (8, $\mathrm{n}=4$ ) long, 0.7-1.2 mm (0.9) wide (Fig. 1A). Proboscis 320-375 (350, $\mathrm{n}=4$ ) long, 160-235 (195) wide, with 12 $(\mathrm{n}=4)$ hook rows, each row with 5-7 hooks (Fig. 1B). Proboscis hook length from anterior: I $25-45(35, \mathrm{n}=6)$, II $35-45(40, \mathrm{n}=6)$, III $35-50(40, \mathrm{n}=6)$, IV 35-50 (40, $\mathrm{n}=6)$, V 35-45 (40, $\mathrm{n}=6)$, VI $25-40(30, \mathrm{n}=6)$, VII 25 $30(\mathrm{n}=2)$. Hook root length from anterior: I 15-25 (20, $\mathrm{n}=6)$, II $25-40(30, \mathrm{n}=6)$, III $25-45(35, \mathrm{n}=6)$, IV 25 $45(35, \mathrm{n}=6), \mathrm{V} 25-40(30, \mathrm{n}=6)$, VI 10-35 $(25, \mathrm{n}=6)$, VII $15(\mathrm{n}=2)$ (Fig. 1C). Apical organ 35-50 (45) long, 25-40 (35) wide (Fig. 1D). Neck 560-900 (765, n=4) long, 230-270 (250) wide at base. Bulb 335-500 (405, $\mathrm{n}=3$ ) long, 250-310 (280) wide (Fig. 1A, E). Mean neck/ body ratio $0.11(1 / 8)$. Proboscis receptacle not complete posteriorly, 685-910 (810, $\mathrm{n}=4)$ long, 185-210 (200) wide; cerebral ganglion $125-150(140, \mathrm{n}=1)$ long, $70-90$ (80) wide (Fig. 1E). Lemnisci 380-620 (475, $\mathrm{n}=4)$ long, 100-160 (125) wide (Fig. 1A, E). Testes oval, post-equatorial, in tandem and slightly overlapping one another, anterior testis 520-780 (630, $\mathrm{n}=4)$ long, 275-460 (340) wide; posterior testis $460-910(645, \mathrm{n}=4)$ long, 245-460 (325) wide (Fig. 1A, F). Six cement glands, pyriform 235-600 (430, $\mathrm{n}=24)$ long, 125-310 (205) wide, fusing posteriorly into 2 common cement reservoirs, 500-865 (690, n = 8) long, 95-150 (115) wide. Saefftigen's pouch, 530-850 (665, $\mathrm{n}=4)$ long, 165-270 (205) wide. Penis up to $75(\mathrm{n}=2)$ long, 55-85 (65) wide (Fig. 1F). Bursa with sensory papillae, 425-650 $(515, \mathrm{n}=4)$ long, 145-350 (290) wide, with 2 bursal pockets (Fig. 1F). Reproductive system post-equatorial, 2.3-4.3 mm (3.1, n = 4), occupying $35-42 \%(39 \%)$ of total length (Fig. 1A).

Female (based on 2 specimens with well-developed ovarian balls): Trunk 4.8-5.7 mm $(5.3, \mathrm{n}=2)$ long, 1.0 $1.1 \mathrm{~mm}(1.0)$ wide. Proboscis $360(\mathrm{n}=1)$ long, 240 wide with $11(n=1)$ hook rows, of 6 or 7 hooks each. Proboscis hook length from anterior: I 40-45 $(\mathrm{n}=2)$, II 45-50 $(\mathrm{n}=2)$, III 30-45 $(\mathrm{n}=2)$, IV 45-50 $(\mathrm{n}=2), \mathrm{V}$ 40-45 $(\mathrm{n}=2)$, VI 35-40 $(\mathrm{n}=2)$, VII not measured. Hook root length from anterior: I $15-25(\mathrm{n}=2)$, II $50-55(\mathrm{n}=2)$, III 30-40 ( $\mathrm{n}=2)$, IV 45-50 ( $=2)$, V 40-45 ( $=2)$, VI 25-30 ( $\mathrm{n}=2)$, VII not measured. Apical organ 45 long, 35 wide. Neck $630(\mathrm{n}=1)$ long, 230 wide at base, bulb 360 long, 250 wide. Mean neck/body ratio 0.12 (1/8). Proboscis receptacle not complete posteriorly, 1,020 $(n=1)$ long, 260 wide, cerebral ganglion 300 long, 150 wide. Lemnisci 495-595 (545, n = 2) long, 150-165 (160) wide. Uterine bell 490 long, 160 wide; uterus 840 long, 120 wide; vagina 205 long, 100 wide (Fig. 1G). Reproductive system $1.5 \mathrm{~mm}$ long, occupying $27 \%$ of total length.

Type host: Gymnotus carapo Linnaeus (Gymnotiformes: Gymnotidae). Vernacular names in Argentina: "morena pintada" or "flecuda". Other names: "banded knifefish", "electric fish".

Type locality: Colastiné River (tributary of Paraná River) $\left(31^{\circ} 40^{\prime} \mathrm{S}, 60^{\circ} 46^{\prime} \mathrm{W}\right)$, near Barrio Colastiné Sur, Santa Fe Province, Argentina.

Site of infection: Middle and posterior intestine.

Prevalence: $7 \%(4 / 58)$.

Mean intensity: 2 (range 1-3).

Mean abundance: 0.1 .

Type materia 1: Holotype MACN-Pa No. 496/1 (male); allotype MACN-Pa No. 496/2 (female) and paratypes, MACN$\mathrm{Pa}$ No. 496/3 (male), MACN-Pa No. 496/4 (2 males and 1 immature), MACN-Pa No. 496/5 (female) and IPCAS No. A-81 (male) from Colastiné River, Santa Fe Province.

E t y m o log y: The species is dedicated to the first author's father, Mr. Omar Segundo Arredondo, for his enthusiastic help in collecting fishes.

\section{DISCUSSION}

There are two main features to discriminate the genera Paralongicollum Amin, Bauer et Sidorov, 1991 and Pomphorhynchus Monticelli, 1905, the morphology of the neck and proboscis. The new species does not belong to Paralongicollum because it has a neck not uniformly cylindrical (vs. a neck uniformly cylindrical) and a proboscis cylindrical (vs. a proboscis enlarged anteriorly) (see Amin et al. 2003).

Species of the genus Pomphorhynchus are widely distributed, being found mostly in freshwater fishes, a few in marine fishes and one in an amphibian host (Petrochenko 1956, Yamaguti 1963, Golvan 1969, Golvan and Buron 1988, Amin et al. 2003). A total of 24 species are recognised as valid (Amin et al. 2003, Olmos and Habit 2007), 4 of which are parasites of freshwater fishes in South America, P. moyanoi Olmos et Habit, 2007, parasite of Percilia gillisi Girard from Chile; P. patagonicus Ortubay, Ubeda, Semenas et Kennedy, 1991, parasite of Odontestes hatcheri (Eigenmann) (syn. Patagonina hatcheri Eigenmann) (see Froese and Pauly 2010), Galaxias platei Steindachner, Percichthys trucha (Valenciennes), Oncorhynchus mykiss (Walbaum) and Salvelinus fontinalis (Mitchill) from Argentina; P. sphaericus Gil de Pertierra, Spatz et Doma, 1996 (syn. P. patii Lunaschi, 1997, see Amin et al. 2003), parasite of Pimelodus maculatus Lacépède, P. albicans (Valenciennes), Iheringhichthys labrosus (Lütken) (syn. Iheringhichthys platanus) (see 


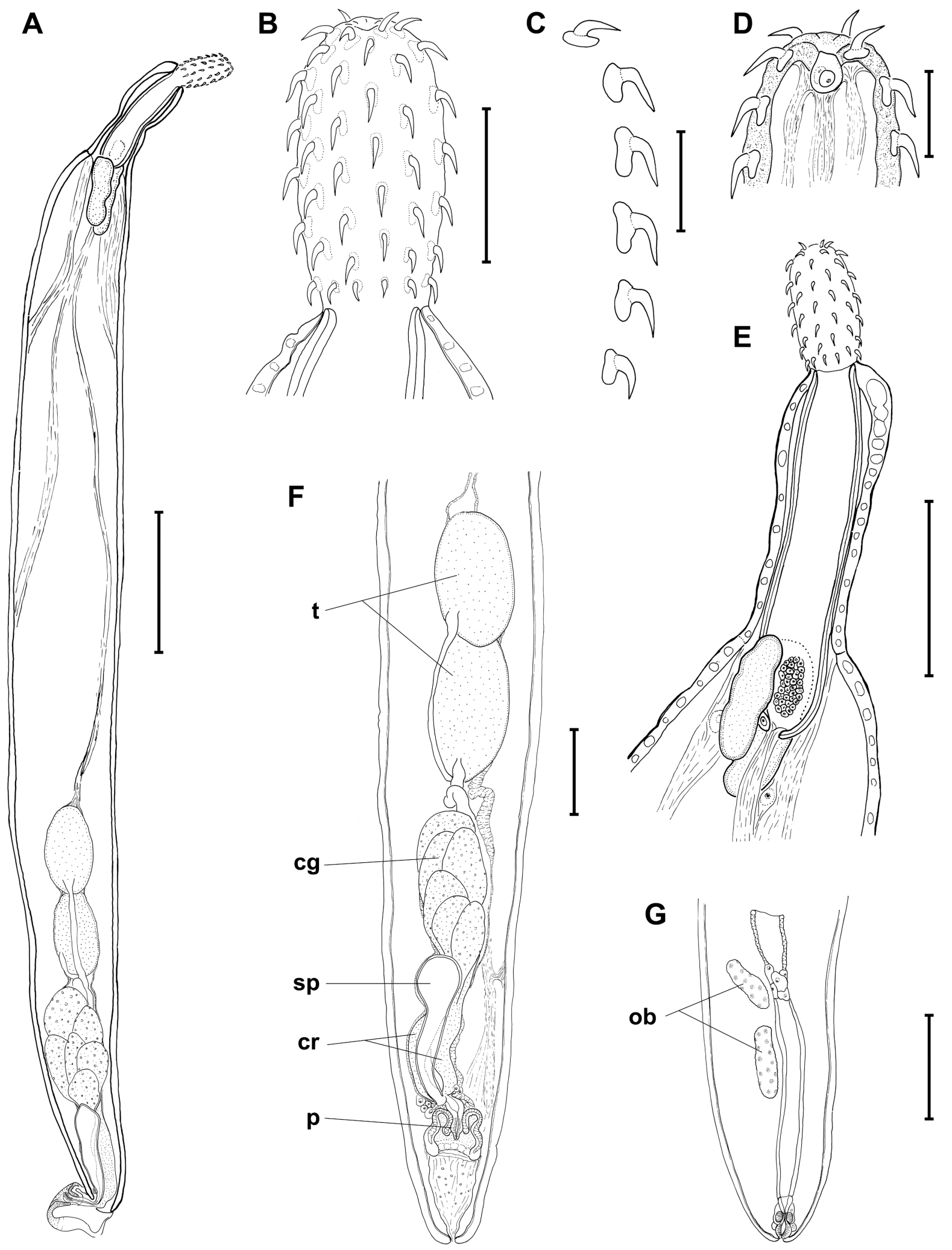

Fig. 1. Pomphorhynchus omarsegundoi sp. n. from Gymnotus carapo. A - lateral view of a complete male specimen (MACN-Pa 496/1); B - armature of male proboscis (IPCAS A-81); C - detail of hook row showing roots in male (MACN-Pa 496/1); D - detail of proboscis tip showing the apical organ (MACN-Pa 496/1); $\mathbf{E}$ - detail of neck showing the inconspicuous asymmetrical bulb (IPCAS A-81); F - dorsoventral view of male reproductive system (MACN-Pa 496/4); G - dorsoventral view of female reproductive system (MACN-Pa 496/5). Abbreviations: cg - cement glands; cr - cement reservoir; ob - ovarian balls; $\mathrm{p}$ - penis; sp - Saeftigen's pouch; $\mathrm{t}$ - testis. Scale bars: $\mathrm{A}=1 \mathrm{~mm} ; \mathrm{B}=200 \mu \mathrm{m} ; \mathrm{C}, \mathrm{D}=100 \mu \mathrm{m} ; \mathrm{E}-\mathrm{G}=500 \mu \mathrm{m}$. 
Froese and Pauly 2010), Parapimelodus valenciennis (Lütken) and Luciopimelodus pati (Valenciennes) from Argentina; and P. yamagutii Schmidt et Hugghins, 1973 (Schmidt and Hugghins 1973b), parasite of Percichthys melanops Girard from Chile.

The new species is characterised by the following combination of features: a small body; a non-spirally twisted long neck forming an inconspicuous asymmetrical bulb more developed dorsally than ventrally; a proboscis almost cylindrical, possessing 11 or 12 longitudinal rows of 5 to 7 (usually 6) hooks each; presence of an apical organ; a mean neck/body ratio of about $1 / 8$; and a post-equatorial male reproductive system.

Pomphorhynchus omarsegundoi differs from P. sphaericus mainly in having a small asymmetrical bulb instead of a large spherical bulb, a lower number of hooks per row (5-7 vs. 14-16), and in root shape (manubrium-shaped roots vs. some roots formed by a wide sheet splitting into two posterior apophyses and others showing an anterior quadrangular sheet and a posterior slender sheet).

The new species shares with $P$. moyanoi, $P$. patagonicus and $P$. yamagutii the presence of an asymmetrical bulb more developed dorsally than ventrally, but differs from them in having an inconspicuous bulb without protuberances (250-310 vs. $300-1,300,500-1,800$ and 440550 wide), and a lower number of hooks per row (5-7 vs. 13-14, 13-14 and 9-10). The new species can also be distinguished from the other South American species by the markedly post-equatorial position of the male reproductive system, occupying $35-42 \%$ (39\%) of the total length vs. $70 \%$ (P. moyanoi), 54\% (P. patagonicus), $84 \%$ (P. sphaericus) and 60\% (P. yamagutii) (based on the figures of the original descriptions).

The apical organ was frequently observed in Eoacanthocephala and Archiacanthocephala, but rarely mentioned in Palaeacanthocephala (Dunagan and Miller 1983,
Miller and Dunagan 1985, Dunagan and Bozzola 1992, Herlyn et al. 2001, Herlyn 2001, 2002, Herlyn and Ehlers 2001). In this study, the presence of the apical organ was confirmed for $P$. omarsegundoi and the type material of P. patagonicus and P. sphaericus. Except for Gee (1987), who explicitly reported its absence in $P$. bulbucolli, no mention of this organ was made for any of the 24 species of Pomphorhynchus. Hamann (1891) drew a structure resembling an apical organ in P. laevis (Zoega in Müller, 1776) Van Cleave, 1924 (see Hamann 1891; plate XII, fig. 38); this finding suggests its occurrence in pomphorhynchids from regions other than the one considered in this study.

Pomphorhynchus omarsegundoi constitutes the second species of the genus reported for the Parano-Platense river basin. Pomphorhynchus sphaericus has a wide host range, including several species of pimelodids, while up to date the studied species was only found parasitizing a gymnotiform species.

In Argentina, Gymnotus carapo was found to be parasitized by three species of proteocephalidean cestodes (Gil de Pertierra 2003, 2005) and by the acanthocephalan $P$. omarsegundoi (present paper), while in the Upper Paraná River in Brazil it is parasitized by the following adult helminths: 1 species of proteocephalidean cestode, 1 undetermined species of Digenea, 1 undetermined species of Nematoda and the acanthocephalan Quadrigyrus machadoi Fabio, 1983 (Takemoto et al. 2009).

Acknowledgements. Thanks are due to Lic. Fabián Tricarico, assistant curator of the Parasitological Collection of the Museo Argentino de Ciencias Naturales "Bernardino Rivadavia", Buenos Aires, for loan of type material. Special thanks are also due to the two anonymous referees for their valuable comments that helped to improve this manuscript. This research was supported by ANPCyT (Proj. BID 1728 OC-AR PICT No. 825) and Universidad de Buenos Aires (Grants UBACyT-X443 and X453).

\section{REFERENCES}

Amin O.M., Abdullah S.M.A., Mhaisen F.T. 2003: Description of Pomphorhynchus spindletruncatus n. sp. (Acanthocephala: Pomphorhynchidae) from freshwater fishes in northern Iraq, with the erection of a new pomphorhynchid genus, Pyriproboscis n. g., and keys to genera of the Pomphorhynchidae and the species of Pomphorhynchus Monticelli, 1905. Syst. Parasitol. 54: $229-235$

Dunagan T.T., Bozzola J.J. 1992: Morphology of the apical organ in Macracanthorhynchus hirudinaceus (Acanthocephala). J. Parasitol. 78: 899-903.

Dunagan T.T., Miller D.M. 1983: Apical sense organ of Macracanthorhynchus hirudinaceus (Acanthocephala). J. Parasitol. 69: 897-902.

Froese R., Pauly D. (Eds.) 2010: FishBase. World Wide Web electronic publication. www.fishbase.org, January 2010.

GeE R.J. 1987: A comparative morphological study of the stutzzelle (support cell) in the phylum Acanthocephala. Can. J. Zool. 65: 660-668.
Gil de Pertierra A.A. 2003: Two new species of Nomimoscolex (Cestoda: Proteocephalidea, Monticelliidae) from Gymnotus carapo (Pisces: Gymnotiformes) in Argentina. Mem. Inst. Oswaldo Cruz 98: 345-351.

Gil de Pertierra A.A. 2005: Comparative study of the microtriches of adult cestodes (Proteocephalidea: Monticelliidae), and some comments on their systematic value. Zool. Anz. 243: 295-304.

Gil de Pertierra A.A., Spatz L., Doma I.L. 1996: Systematics and metapopulation dynamics of Pomphorhynchus sphaericus n. sp. (Acanthocephala: Pomphorhynchidae) from freshwater siluriform fishes in the Subtropical Region of Argentina. Res. Rev. Parasitol. 56: 33-39.

Golvan Y.J. 1969: Systématique des acanthocéphales (Acanthocephala Rudolphi 1801). Première partie: L'ordre des Palaeacanthocephala Meyer 1931, première fascicule: la super-famille des Echinorhynchoidea (Cobbold 1876) Golvan et Houin 1963. Mém. Mus. Nat. Hist. Nat., Ser. A, Zool., 57: 1-373. 
Golvan Y.J., Buron I. 1988: Les hôtes des Acanthocéphales. II Les hôtes définitifs. 1. Poissons. Ann. Parasitol. Hum. Comp. 63: 349-375.

Hamann O. 1891: Monographie der Acanthocephalen, I. Teil. Jenaische Z. Naturwiss. 25: 113-231.

Hamann M.I. 1982a: Parásitos del pacú (Colossoma mitrei) del Río Paraná medio, República Argentina (Pisces, Serrasalmidae). Hist. Nat. 2: 153-160.

Hamann M.I. 1982b: Parásitos en peces de la familia Doradidae del Río Paraná medio, República Argentina (Pisces, Siluriformes). Hist. Nat. 2: 193-199.

Hamann M.I. 1982c: Parásitos del sábalo (Prochilodus platensis Holmberg, 1889) del Río Paraná Medio, República Argentina, (Pisces, Tetragonopteridae). Hist. Nat. 2: 233-237.

Herlyn H. 2001: First description of an apical epidermis cone in Paratenuisentis ambiguus (Acanthocephala: Eoacanthocephala) and its phylogenetic implications. Parasitol. Res. 87: 306310 .

Herlyn H. 2002: The musculature of the praesoma in Macracanthorhynchus hirudinaceus (Acanthocephala, Archiacanthocephala): re-examination and phylogenetic significance. Zoomorphology 121: 173-182.

Herlyn H., Ehlers U. 2001: Organisation of the praesoma in Acanthocephalus anguillae (Acanthocephala, Palaeacanthocephala) with special reference to the muscular system. Zoomorphology 121: 13-18.

Herlyn H., Martini N., Ehlers U. 2001: Organisation of the praesoma of Paratenuisentis ambiguus (Van Cleave, 1921) (Acanthocephala: Eoacanthocephala), with special reference to the lateral sense organs and musculature. Syst. Parasitol. 50: 105-116.

Miller D.M., Dunagan T.T. 1985: Functional morphology. In: D.W.T. Crompton and B.B. Nickol (Eds.), Biology of the Acanthocephala. Cambridge University Press, Cambridge, UK, pp. 27-72.

Olmos V.L., Haвiт E.M. 2007: A new Pomphorhynchus (Acanthocephala: Palaeacanthocephala) in freshwater fishes from Central Chile. J. Parasitol. 93: 179-183.

Ortubay S., Ubeda C., Semenas L., Kennedy C. 1991: Pomphorhynchus patagonicus n. sp. (Acanthocephala: Pomphorhynchi- dae) from freshwater fishes of Patagonia, Argentina. J. Parasitol. 77: 353-356.

Ortubay S.G., Semenas L., Ubeda C.A., Quaggiotto A.E., Viozzi G.P. 1994: Catálogo de Peces Dulceacuícolas de la Patagonia Argentina y sus Parásitos Metazoos. Dirección de Pesca, Subsecretaría de Recursos Naturales, Río Negro, Argentina, $110 \mathrm{pp}$.

Petrochenko V.I. 1956: Acanthocephala of Domestic and Wild Animals. Vol. 1. Izdatel'stvo Akademii Nauk SSSR, Moscow. (In Russian. English Translation by Israel Program for Scientific Translation, Jerusalem, Israel, 1971, 465 pp.)

Portes Santos C., Gibson D.I., Tavares L.E.R., Luque J.L. 2008: Checklist of Acanthocephala associated with the fishes of Brazil. Zootaxa 1938: 1-22.

Schmidt G.D., Hugghins E.J. 1973a: Acanthocephala of South American fishes. Part 1, Eoacanthocephala. J. Parasitol. 59: 829-835.

Schmidt G.D., Hugghins E.J. 1973b: Acanthocephala of South American fishes. Part 2. Palaeacanthocephala. J. Parasitol. 59: 836-838.

Semenas L., Trejo A. 1997: Redescription of Acanthocephalus tumescens (von Linstow, 1896) (Palaeacanthocephala: Echinorhynchidae) in Galaxias maculatus (Pisces: Galaxiidae) in Patagonia (Argentina). Syst. Parasitol. 36: 13-16.

Takemoto R.M., Pavanelli G.C., Lizama M.A.P., Lacerda A.C.F., Yamada F.H., Moreira L.H.A., Ceschini T.L., Bellay S. 2009: Diversity of parasites of fish from the Upper Paraná River floodplain, Brazil. Braz. J. Biol. 69: 691-705.

Thatcher V.E. 2006: Amazon Fish Parasites. Pensoft, Sofia/Moscow, 508 pp.

VizCAÍno S.I. 1992: Especie nueva del género Neoechinorhynchus (Acanthocephala - Neoechinorhynchidae) parásita de peces de Argentina. An. Inst. Biol. Univ. Nac. Autón. México, Ser. Zool., 63: $179-184$.

Vizcaíno S.I., LunAschi L.I. 1987: Acantocéfalos de peces argentinos I. Gorytocephalus talaensis sp. nov. (Neoechinorhynchidae) parásita de Curimata biornata (Pisces - Curimatidae). Neotrópica 33: 51-56.

Yamaguti S. 1963: Systema Helminthum. Vol. 5. Acanthocephala. Wiley Interscience, New York, 423 pp. 